\title{
Tinjauan Ekonomi Islam Terhadap Kelayakan Usaha Cabai Merah (Studi Kasus Di Desa Duriasi Kabupaten Konawe)
}

\author{
Leni Saleh \\ Program Studi Agribisnis dan Agroindustri Fakultas Pertanian \\ Universitas Lakidende \\ E-mail : sopiah lenisa@yahoo.com
}

\begin{abstract}
The purpose of this research is to know: (1) The feasibility of red chili pepper in Duriasi village of Konawe regency, and (2) Economic review of Islam to the feasibility of red chili pepper in Duriasi village Konawe regency. The method of determining the sample is purposive. Sampling in this research is conducted by census that is take all population of red chili pepper farmer so that total of respondent is 20 respondents.

Result of research concluded that: (1) Based on analysis result obtained R/C equal to 3,06. The value of $R / C>1$, this means that in the red chili pepper plant undertaken by farmer of respondents in the village Duriasi subdistrict Wonggeduku is efficient or feasible to cultivate and every one rupiah issued will generate revenue of 3,06 rupiah. (2) According to the Islamic economic review of the feasibility of red chili pepper business is accordance with Islamic ekonomic principles because it can realize the level of welfare and increase the level of economic income of family members, especially farmers.
\end{abstract}

Key Words: Feasibility, Red Chili Pepper and Islamic Economics.

\begin{abstract}
Abstrak
Tujuan dari penelitian ini untuk mengetahui: (1) Kelayakan usaha cabai di Desa Duriasi Kabupaten Konawe, dan (2) Tinjauan ekonomi Islam terhadap kelayakan usaha Cabai di Desa Duriasi Kabupaten Konawe. Metode penentuan sampel dilakukan secara sengaja (purposive. Pengambilan sampel dalam penelitian ini dilakukan secara sensus yaitu mengambil semua populasi petani cabai merah, sehingga jumlah total responden sampel adalah 20 orang responden.

Hasil penelitian disimpulkan bahwa: (l) Berdasarkan hasil analisis diperoleh $\mathrm{R} / \mathrm{C}$ sebesar 3,06. Nilai $R / C>1$, hal ini berarti bahwa dalam usaha komoditas tanaman cabai merah yang dilakukan oleh petani responden di Desa Duriasi Kecamatan Wonggeduku adalah efisien atau layak untuk diusahakan dan setiap satu rupiah yang dikeluarkan akan menghasilkan penerimaan sebesar 3, 06 rupiah. (2) Menurut tinjauan ekonomi Islam terhadap kelayakan usaha tanaman cabai merah telah sesuai dengan prinsip Ekonomi Islam karena dapat mewujudkan tingkat kesejahteraan dan meningkatkan tingkat pendapatan ekonomi keluarga masyarakat, khususnya petani.
\end{abstract}

Kata Kunci: Kelayakan Usaha, Cabai Merah dan Ekonomi Islam.

\section{PENDAHULUAN}

Tujuan pembangunan di Indonesia antara lain untuk meningkatkan produksi yang sekaligus meningkatkan $\begin{array}{lrr}\text { pendapatan, } & \text { sehingga } & \text { dapat } \\ \text { meningkatkan taraf hidup masyarakat. } \\ \text { Pembangunan } & \text { diarahkan pada }\end{array}$ 
peningkatan produksi guna memenuhi kebutuhan pangan dan

industri, memperluas kesempatan kerja, dan mendorong kesempatan berusaha. Masih pentingnya pertanian dalam perekonomian dapat dilihat dari aspek kontribusinya terhadap PDB (Produk Domestik Bruto), penyediaan lapangan kerja, penyediaan penganekaragaman menu makanan, kontribusinya untuk mengurangi jumlah kemiskinan dan peranannya terhadap nilai devisa yang akan dihasilkan dari ekspor (Suratiyah, 2008).

Untuk mengukur keberhasilan pembangunan ekonomi suatu daerah diperlukan suatu indikator. Salah satu indikator ekonomi makro yang biasa digunakan adalah besarnya produk domestik regional bruto (PDRB). Sebagai negara agraris, maka pada umumnya daerah-daerah di Indonesia, penyumbang terbesar PDRB adalah sektor pertanian. Dalam merencanakan pembangunan terlebih dahulu harus ditentukan prioritas pembangunan daerah sesuai dengan potensi yang dimiliki oleh daerah yang bersangkutan.Dengan pemahaman tentang ekonomi wilayah akan diketahui sektor-sektor unggulan suatu daerah (syafrisal, 1997).

Indonesia dikenal sebagai negara agraris yang berarti negara yang mengandalkan sektor pertanian sebagai penopang pembangunan juga sebagi sumber mata pencaharian penduduknya. Sektor pertanian membentuk proporsi yang sangat besar bagi devisa negara, penyedia lapangan kerja dan sumber pendapatan masyarakat. Hal ini kemudian menjadikan sektor pertanian sebagai pasar yang potensial bagi produk-produk dalam negeri baik untuk barang produksi maupun barang konsumsi, terutama produk yang dihasilkan oleh subsektor tanaman bahan makanan. Sektor pertanian terus dituntut untuk berperan dalam perekonomian nasional melalui pembentukan Produk Domestik Bruto
(PDB), perolehan devisa, penyediaan pangan dan bahan baku industri, pengentasan kemiskinan, penyediaan lapangan kerja dan peningkatan pendapatan masyarakat (Khazanani, 2011).

Cabai merupakan komoditas sayuran unggulan nasional dan daerah. Komoditas unggulan merupakan komoditas yang layak diusahakan karena memberikan keuntungan kepada petani, baik secara biofisik, sosial maupun ekonomi. Suatu komoditas layak dikembangkan jika komoditas tersebut diusahakan sesuai dengan zona agroekologinya, mampu memberi peluang berusaha, serta dapat dilakukan dan diterima masyarakat setempat sehingga berdampak pada penyerapan tenaga kerja dan secara ekonomi menguntungkan (Susanto dan Sirappa, 2007).

Daya tarik pengembangan cabai bagi petani terletak pada nilai ekonominya yang tinggi. Komoditas cabai sangat besar peranannya dalam menunjang usaha pemerintah untuk meningkatkan pendapatan dan taraf hidup petani, memperluas kesempatan kerja, menunjang pengembangan agribisnis dan melestarikan sumber daya alam (Prajnanta, 1999).

Tanaman cabai merah merupakan tanaman yang memiliki nilai ekonomi tinggi. Hal ini dikarenakan kebutuhan harian komoditas ini untuk masyarakat Indonesia sangat tinggi karena merupakan bahan baku sayuran yang dipakai untuk rumah tangga dan industri (Budiono, 2004).

Permasalahan utama tingginya volume impor cabai disebabkan oleh tidak adanya pengaturan pola tanam. Surplus produksi cabai terjadi pada saat yang bersamaan antar daerah sehingga menyebabkan harga jatuh. Jatuhnya harga cabai membuat petani berhenti menanam yang kemudian menyebabkan pasokan cabai menurun dan harganya meningkat tajam. Untuk mengantisipasi kondisi 
tersebut pemerintah melakukan impor cabai dimana harga cabai impor dijual dengan harga yang lebih murah (Parwadi, 2014).

Budidaya cabai yang berhasil memang menjanjikan keuntungan yang menarik, tetapi tidak jarang petani cabai merah yang menemui kegagalan dan kerugian yang berarti. Untuk keberhasilan dalam usahatani cabai merah selain diperlukan keterampilan dan modal yang cukup, juga banyak faktor yang perlu diperhatikan seperti syarat tumbuh, pemilihan bibit, cara bercocok tanam, pengendalian OPT dan penanganan pasca panen (Hartono, 2015).

Islam mendorong umatnya untuk bekerja dan memproduksi, bahkan menjadikannya sebagai sebuah kewajiban terhadap orang-orang yang mampu, lebih dari itu Allah akan memberikan balasan yang setimpal yang sesuai dengan amal/kerja mereka (Nurul Huda dalam Barokah, 2011). sesuai dengan firman Allah dalam Al-Qur'an dalam QS. AnNahl ayat 97 berikut ini.

Artinya: " Barangsiapa yang mengerjakan amal saleh, baik laki-laki maupun perempuan dalam keadaan beriman, maka sesungguhnya akan kami berikan kepadanya kehidupan yang baik, dan sesungguhnya akan kami beri balasan kepada mereka dengan pahala yang lebih baik dari apa yang telah mereka kerjakan". Depag RI : Al-Qur'an dan Terjemahan, 2002).

Menghadapi kebutuhan akan pangan dan peningkatan pendapatan daerah bagi penguatan ketahanan ekonomi Sulawesi Tenggara diperlukan upaya peningkatan sektor ekonomi. Dimana sektor-sektor ekonomi tersebut diharapkan dapat memberikan kontribusi untuk PDRB Sulawesi Tenggara. Sejak tahun 2014 cabai telah ditetapkan sebagai salah satu komoditas nasional untuk dikembangkan dengan dukungan dana APBN/APBD, disamping itu dilakukan pula upaya penguatan kelembagaan melalui fasilitasi antar petani dengan perusahaan mitra. Provinsi Sulawesi Tenggara telah ditetapkan sebagai bagian dari program pengembangan kawasan untuk beberapa komoditas unggulan (cabai, bawang merah dan jeruk) sesuai Keputusan Menteri Pertanian Republik Indonesia Nomor

45/Kpts/PD.200/1/2015.

Kabupaten Konawe merupakan salah satu penghasil produksi pangan pertanian di Sulawesi Tenggara, dimana sektor pertanian dapat memberikan kontribusi yang positif bagi pendapatan daerah khususnya Sulawesi Tenggara. Bila dilihat dari ruang lingkup makro produksi pertanian masih sangat potensial untuk dikembangkan sebagai aset penggerak perekonomian daerah ini di masa yang akan datang. Dengan berbagai potensi dan peluang terhadap ekonomi daerah, maka diperlukan upaya peningkatan produksi subsektor pertanian agar dapat menambah pemasukan pendapatan daerah Kabupaten Konawe. Pada tahun 2011 Kabupaten Konawe telah mendapat kegiatan program pengembangan kawasan di Kecamatan Wonggeduku sampai sekarang yang sumber anggarannya dari APBN Dinas Perkebunan dan Hortikultura Provinsi Sulawesi Tenggara yang lokasinya ditetapkan dengan Surat Keputusan Kepala Dinas Perkebunan dan Hortikultura Provinsi Sulawesi Tenggara. Berkaitan dengan uraian latar belakang diatas maka tujuan penelitian ini adalah (1) Untuk mengetahui kelayakan usaha cabai merah di Desa Duriasi Kabupaten Konawe; (2) Untuk mengetahui tinjauan ekonomi Islam terhadap kelayakan usaha Cabai merah di Desa Duriasi Kabupaten Konawe.

\section{TINJAUAN PUSTAKA}

\section{A. Deskripsi Tanaman Cabai}

Cabai (Capsicum Annum

merupakan salah satu jenis sayuran yang 
cukup penting di Indonesia, baik sebagai komoditas yang dikonsumsi di dalam negeri maupun sebagai komoditas ekspor. Sebagai sayuran, cabai merah selain memiliki nilai gizi yang cukup tinggi, juga mempunyai nilai ekonomi tinggi. Pemanfaatannya sebagai bumbu masak atau sebagai bahan baku berbagai industri makanan, minuman dan obat-obatan membuat cabai merah semakin menarik untuk diusahakan (Sumarni dan Hidayat, 2005).

Karakteristik lima spesies cabai yang telah dibudidayakan tersebut adalah

1. Capsicum annuum (Capsicum annuum var. Annuum), cabai jenis atau spesies ini memiliki tangkai daun panjang; helai daun tunggal berbentuk ovale atau lanceolate, agak kaku, berwarna hijau sampai hijau tua, dengan tepi yang rata. Daun tumbuh pada tunas-tunas samping secara berurutan, sedangkan pada batang utama daun tunggal tersebut tersusun secara spiral. Bunga tumbuh tunggal atau kadang-kadang berkelompok pada setiap ruas. Pada saat anthesis, tangkai bunga umumnya merunduk. Setiap bunga mempunyai lima helai daun bunga dan lima atau enam helai mahkota bunga yang berwarna putih susu atau kadangkadang ungu. Bunga cabai mempunyai satu kepala putih (stigma), berbentuk bulat, dengan benang sari yang berjumlah enam buah. Daging buah umumnya renyah atau kadang-kadang lunak. Biji berwarna kuning muda. Jenis cabai ini bersifat fasciculate, yaitu sifat tanaman yang buku-bukunya memendek dan terdapat $4-8$ bunga atau buah pada satu ruas. Jenis cabai ini memiliki jumlah kromosom $2 \mathrm{n}=24$.

2. Capsicum frutescens, cabai jenis ini mempunyai tangkai daun pendek, helai daun tungal berbentul ovale, pundak lebar, berwarna hijau atau agak cokelat-keunguan dan mengkilat.
Bunganya tumbuh tunggal atau kadang-kadang bersifat fasciculate. Tangkai bunga tegak saat anthesis, tetapi dengan kuntum bunga yang merunduk. Mahkota bunga berwarna putih kehijau-hijauan tanpa bintik kuning pada dasar cuping. Calyx tidak bergelombang dan cuping bunga hampir rata. Daging buah umumnya lunak, dan posisi buah tegak ke atas. Biji berwarna kuning padi. Jumlah kromosom jenis cabai ini adalah $2 \mathrm{n}=$ 24.

3. Capsicum chinens, sifat tanaman cabai jenis ini hampir sama dengan capsicum annuum. Perbedaan hanya terletak pada sifat bunganya saja. Bunga Capsicum chinens berjumlah dua atau lebih pada setiap ruas, namun kadang-kadang tunggal, dan bersifat bunga majemuk. Tangkai bunga tegak atau merunduk saat anthesis. Mahkota bunga berwarna putih kehijauan, kadang-kadang berwarna putih susu atau ungu, tanpa bintik kuning pada dasar cuping bunga. Pada buah matang, posisi calyx biasanya berlekuk. Daging buah renyah. Biji berwarna kuning jerami. Jumlah kromosom cabai jenis ini adalah $2 \mathrm{n}=24$.

4. Capsicum baccatum (capsicum baccatum var. Pendulum, cabai jenis ini mempunyai tangkai daun yang panjang. Bunga tumbuh tunggal, tangkai bunga tegak atau merunduk saat anthesis. Mahkota bunga berwarna putih kehijauan, terdapat bintik kuning atau hijau pada dasar cuping bunga. Pada buah matang, posisi calyx mempunyai lekukan. Daging buah renyah, biji berwarna kuning mengkilat. Jumlah kromosom cabai jenis ini adalah $2 \mathrm{n}=$ 24.

5. Capsicum pubescens, cabai jenis ini mempunyai bunga tunggal, tangkai bunga tegak saat anthesis, tetapi bunga merunduk. Mahkota bunga berwarna 
ungu, namun ada yang berwarna putih pada ujung cuping, tanpa bintik kungin pada sarr cuping bunga. Pada buah matang, keadaan calyx tidak mepunyai lekukan. Biji berwarna hitam. Cabai jenis ini memiliki jumlah kromosom 2n = 24 (Rukmana, 2001).

Organ-organ tanaman yang penting pada tanaman cabai adalah sebagai berikut :

1. Batang, batang cabai tumbuh tegak berwarna hijau tua dan berkayu. Pada ketinggian batang tertentu akan membentuk percabangan seperti huruf Y. Batangnya berbentuk silindris, berukuran diameter kecil dengan daun lebar.

2. Daun, daun cabai berbentuk lonjong yang berukuran panjang $8-12 \mathrm{~cm}$, lebar $3-5 \mathrm{~cm}$ dan dibagian pangkal dan ujung daun meruncing. Panjang tangkai daunnya berkisar $2-4 \mathrm{~cm}$ yang melekat pada percabangan, sedangkan tulang daunnya berbentuk menyirip.

3. Akar, akar tanaman cabai tumbuh menyebar dalam tanah terutama akar cabang dan akar rambut. Bagian ujung akarnya hanya mampu menembus tanah sampai kedalaman $25-30 \mathrm{~cm}$, oleh karena itu penggemburan tanah harus dilakukan sampai kedalaman tersebut agar perkembangan akar lebih sempurna.

4. Bunga, bunga cabai termasuk berkelamin 2, karena pada satu bunga terdapat kepala sari dan kepala putik. Bunga cabai tersusun dari tangkai bunga yang berukuran panjang $1-2$ cm, kelopak bunga, mahkota bunga dan alat kelamin yang meliputi kepala sari dan kepala putik.

5. Buah, buah cabai jenis hibrida kebanyakan berbentuk memanjang yang berukuran panjang dan lebar sangat bervariasi, tergantung varietasnya. Buah cabai biasanya muncul dari percabangan atau ketiak daun dengan posisi buah menggantung. Berat cabai merah bervariasi sekitar 5 - 25 gram ( Samadi, 2007)

Budidaya cabai yang berhasil memang menjanjikan keuntungan yang menarik, tetapi tidak jarang petani cabai merah yang menemui kegagalan dan kerugian yang berarti. Untuk keberhasilan dalam usahatani cabai merah selain diperlukan keterampilan dan modal yang cukup, juga banyak faktor yang perlu diperhatikan seperti syarat tumbuh, pemilihan bibit, cara bercocok tanam, pengendalian OPT dan penanganan pasca panen (Hartono, 2015).

Buah cabai oleh masyarakat banyak digunakan sebagai bahan penyedap berbagai masakan, oleh perusahaan sebagai bahan baku industri makanan seperti pada perusahaan mie instan, perusahaan makanan dan perusahaan sambal. Minyak atsiri yang terkandung dalam cabai sangat bermanfaat sebagai bahan baku obat-obatan karena bisa menyembuhkan berbagai penyakit seperti pegal-pegal, sesak nafas, obat kuat untuk kaum adam dan beberapa penyakit lainnya (Kahana, 2008).

Tabel 1. Kandungan Gizi Buah Cabai (Setiap 100 gram)

\begin{tabular}{|c|c|c|c|c|c|}
\hline \multirow{2}{*}{ No. } & Komposisi Gizi & \multicolumn{4}{|c|}{ Jenis Cabai } \\
\cline { 3 - 5 } & Hijau besar & $\begin{array}{c}\text { Merah besar } \\
\text { kering }\end{array}$ & $\begin{array}{c}\text { Merah } \\
\text { besar segar }\end{array}$ & $\begin{array}{c}\text { Rawit } \\
\text { segar }\end{array}$ \\
\hline
\end{tabular}




\begin{tabular}{|c|l|c|c|c|c|}
\hline l. & Kalori (kal) & 23,0 & 311,0 & 31,0 & 103,0 \\
2. & Protein (g) & 0,7 & 15,9 & 1,0 & 4,7 \\
3. & Lemak (g) & 0,3 & 6,2 & 0,3 & 2,4 \\
4. & Karbohidrat (g) & 5,2 & 61,8 & 7,3 & 19,9 \\
5. & Kalsium (g) & 14,0 & 160,0 & 29,0 & 45,0 \\
6. & Fosfor (mg) & 23,0 & 370,0 & 24,0 & 85,0 \\
7. & Zat besi (mg) & 0,4 & 2,3 & 0,5 & 2,5 \\
8. & Vitamin A (S.I.) & 260,0 & 576,0 & 470,0 & $11.050,0$ \\
9. & Vitamin Bl (mg) & 0,1 & 0,4 & 0,1 & 0,2 \\
10. & Vitamin C (mg) & 84,0 & 50,0 & 18,0 & 70,0 \\
l1. & Air (g) & 93,4 & 10,0 & 90,9 & 71,2 \\
\hline
\end{tabular}

Sumber : Direktorat Gizi, Depkes RI yang disitasi Rukmana (2001)

Dalam usaha tanaman cabai yang berhasil memang menjanjikan keuntungan yang menarik. Akan tetapi, untuk mengusahakan cabai juga dibutuhkan keterampilan dan modal yang cukup memadai. Selain itu, tidak jarang pengusaha cabai menemukan kegagalan dan kerugian yang berat. Untuk mengantisispasi kemungkinan tersebut diperlukan keterampilan dalam penerapan pengetahuan dan teknik budidaya cabai yang benar sesuai dengan daya dukung agroekosistemnya (Santika, 1999).

\section{B. Ekonomi Islam}

Pengertian Ekonomi Islam secara istilah (terminologi) menurut M. Syauqi Al-Faujani adalah segala aktivitas perekonomian beserta aturan-aturannya yang didasarkan kepada pokok-pokok ajaran Islam tentang ekonomi. Sedangkan menurut Monzer Kahf ekonomi Islam adalah kajian tentang proses dan penangguhan kegiatan manusia yang berkaitan tentang produksi, distribusi dan konsumsi dalam masyarakat muslim ( Surya Pos Artkel dalam Aisyah, 2011).

Ekoniomi Islam merupakan sekumpulan dasar-dasar umum ekonomi yang disimpulkan dari Al Qur'an dan Hadits merupakan bangunan perekonomian yang didirikan atas landasan dasar-dasar tersebut dengan lingkungan dan masanya. Dari pengertian diatas, dapat dijelaskan bahwa kajian dan

pembahasan ekonomi islam berdimensi kerakyatan dengan sistem yang dibangun merupakan representasi dari ajaran dan nilai-nilai islam. Adapun kepentingan atau tujuan dari sistem ekonomi islam merupakan bentuk 'ijtihad' dari penerjemahan ajaran agama (maqasid syari'ah) pada wilayah normatif agar dapat dipraktekkan menjadi sistem yang aplikatif pada wilayah sosial (kerakyatan) (Dahlan, 2009)

Tujuan Ekonomi Islam membawa kepada konsep al-falah (kejayaan) di dunia dan akhirat, sedangkan Ekonomi Sekuler untuk kepuasan di dunia saja. Ekonomi Islam meletakkan manusia sebagai khalifah di muka bumi ini dimana segala bahan-bahan yang ada di bumi dan di langit adalah diperuntukkan untuk manusia (Nasution, 2007).

Manusia merupakan elemen hidup dan pokok dari setiap program pembangunan, mereka adalah tujuan sekaligus sebagai sasaran pembangunan, dan apabila mereka tidak dipersiapkan secara tepat untuk dapat memberikan kontribusi positif terhadap pembangunan, dan kepentingan dirinya tidak dilindungi dalam batas-batas kesejahteraan sosial, tidak mungkin akan berhasil mengaktualisasikan tujuantujuan pokok Islam dalam pembangunan (Chapra dalam Barokah, 2011).

Islam menganjurkan umatnya untuk memproduksi dan berperan dalam berbagai bentuk aktivitas ekonomi, 
pertanian, perkebunan, perikanan, perindustrian dan perdagangan. Islam memberkati pekerjaan dunia ini dan menjadikannya bagian dari pada ibadah dan jihad. Bekerja adalah bagian dari ibadah dan jihad jika sang pekerja bersikap konsisten terhadap peratuaran Allah, suci niatnya, dan tidak melupakanNya. Dengan bekerja, masyarakat bisa melaksanakan tugas kekhalifahannya, menjaga diri dari maksiat, dan meraih tujuan yang lebih besar. Demikian pula dengan bekerja seorang individu mampu memenuhi kebutuhannya, mencukupi kebutuhan keluarganya, dan berbuat baik kepada tetangganya. Semua hal tersebut tidak akan terwujud tanpa harta yang dapat diperoleh dengan bekerja (Qardhawi, 1997).

Syarat Islam memuat ajaran-ajaran yang mengatur manusia untuk bekerja dan mencari nafkah dengan jalan halal. Aturan-aturan yang berlaku bagi rumah tangga muslim di dalam bekerja dan berusaha (Sahatan, 1998).

\section{Kelayakan Usaha}

Analisis kelayakan adalah suatu dasar pertimbangan dalam mengambil keputusan berusahatani, apakah yang diusahakan layak untuk dikembangkan atau tidak layak untuk dikembangkan (Suratiyah, 2008). Definisi lain analisis kelayakan usaha adalah kegiatan untuk menilai sejauh mana manfaat yang dapat diperoleh dalam melaksanakan suatu kegiatan usaha. Kelayakan usaha digunakan sebagai bahan pertimbangan dalam mengambil keputusan, apakah menerima atau menolak dari suatu gagasan usaha (Kasmir dan Jakfar, 2009).

Pengukuran kelayakan dapat ditinjau dari beberapa beberapa pendekatan salah satunya pendekatan R/C. R/C Rasio merupakan metode analisis untuk mengukur kelayakan usaha dengan menggunakan rasio penerimaan (revenue) dan biaya (cost) (Darsono, 2008).
Secara sederhana dapat ditulis rumus perhitungan $\mathrm{R} / \mathrm{C}$ Rasio

$\mathrm{R} / \mathrm{C}$ rasio $=\underline{\text { Total Penerimaan }}$

Total Biaya

\begin{tabular}{|c|c|}
\hline $\mathrm{R} / \mathrm{C}$ ratio $=\{(\mathrm{Py}$ & $\mathrm{y} \cdot \mathrm{Y}) /(\mathrm{TFC}+\mathrm{TVC})\}$ \\
\hline Total Penerimaa & $=\mathrm{Py} \cdot \mathrm{Y}$ \\
\hline Total Biaya & $=\mathrm{TFC}+\mathrm{TVC}$ \\
\hline Keterangan & $:$ \\
\hline $\mathrm{P}_{\mathrm{y}}$ & = Harga output \\
\hline Y & $=$ Jumlah Output \\
\hline TFC & $\begin{aligned}= & \text { Total Biaya tetap (fixed } \\
& \text { cost) }\end{aligned}$ \\
\hline TVC & $\begin{aligned}= & \text { Total Biaya tidak tetap } \\
& \text { (variable cost) }\end{aligned}$ \\
\hline
\end{tabular}

Dengan kriteria hasil :

(variable cost)

- Jika R/C ratio > l usaha menguntungkan dan layak

- Jika R/C ratio < 1 usaha tidak menguntungkan dan tidak layak

Jika $\mathrm{R} / \mathrm{C}$ ratio = 1 usaha impas (tidak untung maupun merugi)

(Rahmanto et al, (1998) dalam Elisabeth et al (2006)).

Biaya produksi itu dapat dikategorikan sebagai berikut:

(1). Biaya Tetap (Fixed Cost)

Biaya tetap yang tidak ada kaitannya dengan jumlah barang yang diproduksi Biaya tetap tidak habis digunakan dalam satu masa produksi .Contohnya : Sewa tanah dan pajak.

(2). Biaya Tidak Tetap (Variabel Cost)

Biaya yang berubah apabila ada sesuatu usahanya berubah. Biaya ini ada apabila ada sesuatu barang yang diproduksi. Contohnya : Biaya Saprodi.

(3). Biaya Total (Total Cost)

Keseluruhan biaya tetap produksi yang diperoleh dari penjumlahan total biaya tetap dan biaya variabel. Biaya total dapat dirumuskan sebagai berikut :

TC $=$ TFC + TVC

Keterangan :

TC $=$ Total Cost (Total Biaya)

TFC =Total Fixed Cost (Total Biaya Tetap) 
TVC $=$ Total Variable Cost $($ Total Biaya Variabel) (Soekartawi dalam Leni, 2010).

Pendapatan yang dihitung adalah pendapatan atas biaya tunai yaitu selisih antara penerimaan tunai dengan biaya tunai yang dikeluarkan. penerimaan tunai adalah nilai uang yang diterima dari penjualan produk, sedangkan biaya tunai adalah jumlah yang dibayarkan untuk pembelian barang dan jasa. Biaya tunai juga diartikan sebagai biaya yang dikeluarkan untuk pembayaran kas yang dikenal dengan biaya eksplisit antara lain upah yang dibayarkan, pembayaran untuk berbagai bahan yang digunakan, biaya sarana umum dan biaya lainnya, sedangkan biaya implisit merupakan biaya yang tidak melibatkan pengeluaran kas atau berkaitan dengan setiap keputusan yang sulit dihitung (Soekartawi dalam Leni, 2010).

Pendapatan secara sistematis dapat dirumuskan sebagai berikut:

$\mathrm{NR}=\mathrm{TR}-\mathrm{TC}$

$\mathrm{NR}=\mathrm{P} . \mathrm{Q}-(\mathrm{TFC}+\mathrm{TVC})$

Keterangan :

$\mathrm{NR}=$ Net Revenue/ Pendapatan

$\mathrm{TR}=$ Total Revenue/ Penerimaan Total

TC = Total Cost / Biaya Total

TFC = Total Fixed Cost $/$ Biaya Tetap

Total

TVC $=$ Total Variable Cost $/$ Biaya

Variabel Total

Py = Harga output

$\mathrm{Y} \quad=$ Jumlah output

Total penerimaan petani cabai adalah hasil dari perkalian antara jumlah produksi yang dihasilkan dari usahatani cabai (jumlah panen) dengan harga jual. Dirumuskan sebagai berikut :

$\mathrm{TR}=\mathrm{P} \cdot \mathrm{Q}$

Keterangan :

$\mathrm{TR}=$ Total revenue (Rp)

$\mathrm{P} \quad=$ Harga output yang dihasilkan (Rp)

$\mathrm{Q} \quad=$ Jumlah ouput yang dihasilkan (Kg)

\section{METODE PENELITIAN}

\section{A. Lokasi dan Waktu Penelitian}

Lokasi penelitian ini dilakukan di Desa Duriasi Kecamatan Wonggeduku Kabupaten Konawe. Pemilihan lokasi dilakukan secara sengaja (purposive). Dengan pertimbangan bahwa daerah tersebut merupakan salah satu kecamatan sentra komoditi hortikultura (sayursayuran termasuk cabai merah) dan saat ini merupakan lokasi program pengembangan kawasan komoditas cabai merah. Penelitian ini dilaksanakan pada bulan Juni sampai Oktober 2017.

\section{B. Populasi dan Sampel}

Pengambilan sampel dalam penelitian ini dilakukan secara sensus. Metode sensus adalah pengambilan sampel penelitian dengan mengambil semua populasi petani cabai merah, sehingga jumlah total petani sampel adalah 20 orang petani.

\section{Jenis Dan Teknik Pengumpulan Data}

Jenis data yang dikumpulkan adalah data primer dan data sekunder. Data primer adalah data yang langsung dikumpulkan dari petani sebagai responden, sesuai dengan daftar pertanyaan yang telah disiapkan. Sedangkan data sekunder meliputi gambaran umum wilayah penelitian, yang diperoleh dari Badan Pusat Statistik BPS), Dinas Tanaman Pangan Hortikultura dan perkebunan yang terkait literatur, dan laporan yang ada kaitannya dengan penelitian.

Teknik pengumpulan data yang digunakan dalam penelitian ini adalah sebagai berikut:

1. Observasi

Teknik observasi, yaitu merupakan metode pengumpulan data yang meliputi kegiatan pemusatan perhatian secara langsung terhadap sesuatu obyek dengan menggunakan seluruh alat indra. 
2. Wawancara

Teknik wawancara, yaitu pengumpulan data yang dilakukan dengan cara menanyakan langsung responden petani dengan menggunakan daftar pertanyaan.

3. Pencatatan

Teknik pencatatan, yaitu pengumpulan data yang dilakukan dengan cara mencatat data-data yang diperlukan baik dari responden, informan maupun dari instansi terkait yang memiliki data pendukung dalam penelitian ini (Arikunto, 2010).

\section{Teknik Analisis Data}

Analisis data adalah suatu proses penyusunan data agar dapat ditafsirkan. Penelitian ini menggunakan metode deskriptif. Metode deskriptif adalah suatu metode yang berfungsi untuk mendeskripsikan atau memberi gambaran terhadap obyek yang diteliti melalui data atau sampel yang telah terkumpul sebagaimana adanya tanpa melakukan analisis dan membuat kesimpulan yang berlaku untuk umum (Sugiyono, 2011).

Dalam penelitian ini digunakan dua metode analisis, yaitu metode deskriptif kualitatif dan metode Analisis kuantitatif. Metode tersebut dijelaskan sebagai berikut :

1. Untuk tujuan penelitian yang pertama menggunakan metode kuantitatif untuk menganalisis kelayakan usaha cabai merah di Desa Duriasi Kecamatan Wonggeduku Kabupaten Konawe. Rumus analisis pendapatan petani cabai digunakan persamaan berikut :

$\mathrm{NR}=\mathrm{TR}-\mathrm{TC}$

$\mathrm{TR}=\mathrm{Py} . \mathrm{Y}$

$\mathrm{TC}=\mathrm{TFC}+\mathrm{TVC}$

Keterangan :

NR = Net Revenue/ Pendapatan

$\mathrm{TR}=$ Total Revenue/ Penerimaan Total

TC = Total Cost $/$ Biaya Total
TFC = Total Fixed Cost/ Biaya Tetap

Total

TVC = Total Variable Cost $/$ Biaya

Variabel Total

Py = Harga output

Y = Jumlah output

Rumus kelayakan usaha cabai digunakan persamaan berikut:

$\mathrm{R} / \mathrm{C} \quad$ TotalPenerimaan

Total Biaya

$\mathrm{R} / \mathrm{C}$ ratio $=\{(\mathrm{Py} \cdot \mathrm{Y}) /(\mathrm{TFC}+\mathrm{TVC})\}$

Dimana :

Penerimaan $=$ Py. Y

Total Biaya $=$ TFC + TVC

Keterangan

Py = Harga output

$\mathrm{Y} \quad=$ Jumlah output

TFC = Total Biaya tetap (fixed cost)

TVC = Total Biaya tidak tetap

(variable cost)

Dengan kriteria hasil :

- Jika R/C > 1 usaha agribisnis cabai layak untuk diusahakan .

- Jika R/C < l usaha agribisnis cabai tidak layak untuk diusahakan.

- Jika R/C = 1 usaha agribisnis cabai impas (tidak untung maupun merugi).

(Soekartawi dalam Leni, 2010)

2. Untuk tujuan penelitian yang kedua yaitu tinjauan Ekonomi Islam terhadap kelayakan usaha tanaman cabai merah menggunakan analisis deskriptif kualitatif.

\section{HASIL DAN PEMBAHASAN}

A. Deskripsi Daerah Penelitian

Kecamatan Wonggeduku terletak di Wilayah Kabupaten Konawe, secara astronomis Kecamatan Wonggeduku terletak antara 3057.723 Lintang Selatan dan antara $122^{\circ} 09.416$ Bujur Timur. Batas wilayah administrasi Kecamatan Wonggeduku, ebelah Utara berbatasan dengan Kecamatan Wawotobi, sebelah Timur berbatasan dengan Kecamatan Pondidaha, sebelah Selatan berbatasan 
dengan Kecamatan Lambuya dan sebelah Barat berbatasan dengan Kecamatan Wonggeduku Barat.

Tahun 2015 telah terjadi pemekaran wilayah Kecamatan Wonggeduku menjadi Kecamatan Wonggeduku Barat dan Kecamatan Wonggeduku, akibat pemekaran menjadi dua Kecamatan maka luas wilayah Kecamatan Wonggeduku menjadi berkurang yaitu ; $11.376 \mathrm{Ha}$ atau 1,71 persen dari luas daratan Kabupaten Konawe. Desa dengan wilayah terbesar adalah Desa Wonggeduku dengan luas $750 \mathrm{Ha}$ atau 6,5 persen dari luas Kecamatan Wonggeduku. Sedangkan Desa dengan luas wilayah terkecil adalah Desa Polandangi dengan luas $155 \mathrm{Ha}$ atau 1,3 persen dari luas Kecamatan Wonggeduku. Ibukota Kecamatan Wonggeduku terletak di Kelurahan Puuduria, jarak ibukota Kecamatan terhadap Kabupaten adalah $26 \mathrm{Km}$ dan jarak ibukota Kecamatan terhadap Provinsi adalah $54 \mathrm{Km}$ (BPS Konawe, 2015).

Penduduk Kecamatan Wonggeduku memiliki struktur umur muda, dimana sebanyak 1.926 .216 (61,43 persen) adalah dewasa atau penduduk usia produktif (1564 tahun). Kemudian penduduk usia anak-anak (usia 0-14 tahun) sebesar 7.511 jiwa (35,14 persen) dan sisanya 3,43 persen atau 734 jiwa adalah penduduk lanjut usia (65 - 69 tahun keatas) (BPS Kab. Konawe 2015).

Lapangan usaha utama warga Kecamatan Wonggeduku adalah dibidang pertanian, pedagang, industri, tukang kayu, tukang batu dan jasa lainnya. Sebagian besar penduduk di Kecamatan Wonggeduku bermata pencaharian sebagai petani yang sebagian dari mereka juga melakukan usaha tani tanaman cabai.

\section{B. Karakteristik Responden \\ 1. Umur Responden \\ Kemampuan yang dicapai oleh seorang petani dalam melakukan aktivitas produksi usahatani banyak ditentukan}

oleh faktor umur. Umur berpengaruh terhadap kemampuan fisik dan dan cara berfikir seorang petani. Umur produktif kisaran antara 15-55 tahun dan umur non produktif adalah diatas 55 tahun (Soeharjo dan Patong (1984) dalam Leni (2010) .

Untuk lebih jelasnya klasifikasi umur responden dapat dilihat pada tabel diberikut ini:

Tabel 2. Distribusi Umur Responden di

Desa Duriasi Kabupaten Konawe Tahun 2017.

\begin{tabular}{|c|l|c|c|}
\hline No. & Umur & $\begin{array}{c}\text { Jumlah } \\
\text { Responden } \\
\text { (KK) }\end{array}$ & $\begin{array}{c}\text { Persentase } \\
(\%)\end{array}$ \\
\hline 1. & $\begin{array}{l}\text { Umur } \\
\text { Produktif } \\
(15-55) \\
\text { thn }\end{array}$ & 20 & 100,00 \\
\hline 2. & $\begin{array}{l}\text { Umur } \\
\text { non } \\
\text { produktif } \\
>55 \text { thn }\end{array}$ & 0,00 \\
\hline \multicolumn{2}{|c|}{ Total } & 20 & 100,00 \\
\hline
\end{tabular}

Berdasarkan pada Tabel 2 diatas menunjukkan bahwa umur petani responden berkisar antara 15 tahun sampai 55 tahun, dimana 20 responden (100,00 persen) merupakan umur produktif. Umur produktif akan mempengaruhi kemampuan fisik dalam bekerja, berfikir dan bertindak.

2. Tingkat Pendidikan

Tingkat pendidikan responden merupakan salah satu faktor yang dapat mempengaruhi keberhasilan kegiatan usahatani tanaman cabai merah. Tingkat pendidikan akan memberikan pengaruh positif terhadap kemampuan melakukan usahatani cabai merah dalam mengadobsi teknologi dan informasi baru, maupun pengambilan keputusan terkait dengan usaha budidaya cabai merah yang dilakukannya, baik berupa pemilihan benih, teknik budidaya, penanganan 
pasca panen hingga perolehan informasi pasar dan sumber-sumber permodalan.

Tabel 3. Distribusi Responden Menurut

Tingkat Pendidikan di Desa Duriasi

Kabupaten Konawe Tahun 2017

\begin{tabular}{|c|l|c|c|}
\hline $\begin{array}{c}\text { No } \\
\cdot\end{array}$ & $\begin{array}{c}\text { Tingkat } \\
\text { Pendidik } \\
\text { an }\end{array}$ & $\begin{array}{c}\text { Jumlah } \\
\text { Respond } \\
\text { en (KK) }\end{array}$ & $\begin{array}{c}\text { Persenta } \\
\text { se } \\
(\%)\end{array}$ \\
\hline 1. & SD & 2 & 10,00 \\
\hline 2. & SMP & 8 & 40,00 \\
\hline 3. & SMA & 9 & 45,00 \\
\hline 4. & Sl & 1 & 5,00 \\
\hline \multicolumn{2}{|c|}{ Total } & 20 & 100,00 \\
\hline
\end{tabular}

Berdasarkan Tabel 3 diatas menunjukkan bahwa tingkat pendidikan formal petani cabai merah di Desa Duriasi Kecamatan Wonggeduku, sebagian besar adalah setingkat $S 1$ yaitu 5,00 persen, SMA 45,00 persen, setingkat SMP 40,00 persen, S1 5,00 persen dan berpendidikan SD 10,00 persen, hal ini menjelaskan bahwa tingkat pendidikan responden secara umum dapat dikatakan sudah memadai. Pendidikan merupakan salah satu faktor yang sangat penting bagi petani cabai merah dalam pengambilan keputusan yang menyangkut usahataninya.

3. Pengalaman usaha tanaman cabai merah

pengalaman menurut usahataninya yaitu petani dapat dikatakan cukup berpengalaman, apabila telah menggeluti bidang kerjanya selama 5-10 tahun, 10 tahun keatas dikategorikan sangat berpengalaman dan kurang dari 4 tahun dikategorikan sebagai kurang berpengalaman (Soeharjo dan Patong) dalam Leni, 2010).

Pengalaman usaha komoditas tanaman cabai merah merupakan salah satu faktor penting dalam mendukung keberhasilan usahatani. Pengelompokkan petani menurut pengalaman responden disajikan dalam Tabel 4.
Tabel 4. Distribusi Responden Menurut Pengalaman di Desa Duriasi Kabupaten Konawe Tahun 2017.

\begin{tabular}{|c|l|c|c|c|}
\hline $\begin{array}{c}\text { N } \\
\text { o. }\end{array}$ & $\begin{array}{c}\text { Pengala } \\
\text { man } \\
\text { (thn) }\end{array}$ & $\begin{array}{c}\text { Kate } \\
\text { gori }\end{array}$ & $\begin{array}{c}\text { Jumlah } \\
\text { Respo } \\
\text { nden }\end{array}$ & $\begin{array}{c}\text { Persen } \\
\text { tase } \\
(\%)\end{array}$ \\
\hline 1. & $1-4$ & $\begin{array}{c}\text { Kura } \\
\text { ng }\end{array}$ & 2 & 10,00 \\
\hline 2. & $5-10$ & $\begin{array}{c}\text { Cuku } \\
\mathrm{p}\end{array}$ & 12 & 60,00 \\
\hline 3. & $11-30$ & $\begin{array}{c}\text { Sanga } \\
\mathrm{t}\end{array}$ & 6 & 30,00 \\
\hline \multicolumn{5}{|c|}{ Total } \\
Berdasarkan pengalaman petani
\end{tabular}

responden dilokasi penelitian dalam usaha komoditas tanaman cabai merah, sebanyak 2 responden atau 10,00 persen masuk kategori kurang berpengalaman, 12 responden atau 60,00 persen masuk kategori cukup berpengalaman dan 6 responden atau 30,00 persen pada kategori sangat berpengalaman. Di Desa Duriasi Kecamatan Wonggeduku yang melakukan usahatani cabai merah dan memiliki pengalaman paling lama, yaitu sekitar 30 tahun. Informasi yang diperoleh dari para responden menunjukan bahwa usaha cabai merah telah lama diusahakan.

4. Jumlah Tanggungan Keluarga

Tenaga kerja merupakan salah satu faktor produksi yang mempengaruhi produktivitas hasil. Di Indonesia, tenaga kerja usahatani kecil umumnya berasal dari keluarga dan tetangga petani dan tenaga kerja ini tidak diupah. Banyak sedikitnya tenaga kerja yang profesional akan mempengaruhi nilai produksi yang dihasilkan (Mubyarto dalam Asriya, 2012).

Jumlah tanggungan keluarga dalam petani merupakan hal yang perlu untuk mendapatkan tenaga kerja yang produktif selain itu tenaga kerja non upah untuk meminimalisir pengeluaran terhadap tenaga kerja diluar keluarga. Rata-rata jumlah tanggungan keluarga petani dapat dilihat pada tabel 5 . 
Tabel 5. Jumlah Anggota Keluarga Responden Cabai Merah di Desa Duriasi Kabupaten Konawe Tahun 2017.

\begin{tabular}{|c|c|c|c|}
\hline $\begin{array}{c}\text { N } \\
\text { o }\end{array}$ & $\begin{array}{c}\text { Jumlah } \\
\text { anggota } \\
\text { keluarg } \\
\text { a } \\
\text { (Jiwa) }\end{array}$ & $\begin{array}{c}\text { Jumlah } \\
\text { responde } \\
\text { n } \\
(\mathrm{KK})\end{array}$ & $\begin{array}{c}\text { Persentas } \\
\mathrm{e} \\
\mathbf{( \% )}\end{array}$ \\
\hline 1. & $1-4$ & 18 & 90,00 \\
\hline 2. & $5-6$ & 2 & 10,00 \\
\hline \multicolumn{2}{|c|}{ Total } & 20 & 100,00 \\
\hline
\end{tabular}

Pada Tabel 5, menunjukkan bahwa jumlah tanggungan keluarga petani cabai merah pada lokasi penelitian di Desa Duriasi Kecamatan Wonggeduku sebagian besar memiliki tanggungan keluarga pada kisaran 1 - 4 jiwa dengan presentase 90,00 persen, dan petani yang memiliki tanggungan keluarga pada kisaran 5 - 6 jiwa atau sebesar 10,00 persen. Jumlah tanggungan keluarga yang besar menyebabkan besarnya biaya hidup yang harus ditanggung oleh kepala keluarga, sehingga memotivasi petani untuk berusaha lebih giat dan tekun guna memperoleh pendapatan yang dapat mencukupi kebutuhan hidup keluarganya (Dinas Pertanian , 2015).

\section{Analisis Kelayakan Usaha Komoditas Tanaman Cabai Merah}

Produksi yang dimaksudkan dalam penelitian ini adalah produksitanaman cabai merah petani responden selama satu kali musim panen, produksi cabai merah yang diperoleh petani responden dapat dilihat pada Tabel 6 berikut.

Tabel 6. Distribusi Produksi Cabai Merah Responden Di Desa Duriasi Kecamatan Wonggeduku Kabupaten Konawe, Tahun

\begin{tabular}{|c|c|c|c|}
\hline No & $\begin{array}{c}\text { Produks } \\
\text { i (Kg) }\end{array}$ & $\begin{array}{c}\text { Jumlah } \\
\text { Respode } \\
n\end{array}$ & $\begin{array}{c}\text { Presentas } \\
\text { e }\end{array}$ \\
\hline 1. & $<2.668$ & 10 & 50,00 \\
2. & $>2.668$ & 10 & 50,00 \\
\hline
\end{tabular}

\begin{tabular}{|l|l|l|}
\hline Jumlah & 20 & 100,00 \\
\hline
\end{tabular}

Berdasarkan tabel 6 diatas menunjukkan bahwa petani responden sebanyak 10 orang petani respoden atau $\%$ hasil produksinya kurang dari 2.668 $\mathrm{kg}$, dimana yang paling sedikit hasil produksinya adalah sebesar $1000 \mathrm{~kg}$, dan sebanyak 10 orang petani respoden atau $50 \%$ hasil produksi lebih dari $2.668 \mathrm{~kg}$, dimana produksi terbanyak adalah sebanyak $5000 \mathrm{~kg}$.

Biaya produksi adalah kebutuhan masukan yang dipergunakan dalam proses produksi. Biaya dalam proses produksi dapat dibagi dua yaitu biaya tetap dan biaya tidak tetap. Biaya tetap adalah biaya yang relatif tetap jumlahnya dan akan terus dikeluarkan walaupun proses produksi banyak atau sedikit. Biaya tidak tetap didefinisikan sebagai biaya yang jumlahnya dipengaruhi oleh produksi yang diperoleh. Sehingga jumlah biaya tetap yang dikeluarkan oleh 20 orang responden adalah rata-rata sebesar Rp 37.266.375,- dengan rata-rata sebesar Rp 3.549.179,- Sedangkan jumlah biaya variabel adalah sebesar $\mathrm{Rp}$ 224.378.000,- dengan rata-rata sebesar Rp 21.369.333,- Sehingga total biaya adalah sebesar Rp 261.644.375,- dengan rata-rata sebesar Rp 24.918.512,-.

Penerimaan usaha adalah perkalian antara produksi yang diperoleh dengan harga jual. Jumlah produksi adalah hasil yang diperoleh dari cabang usaha (dalam hal ini usahatani) yang diusahakan, sedangkan harga jual adalah nilai atau harga dari usaha (dalam hal ini usahatani) per satuan produksi. Berdasarkan hasil penelitian menunjukkan bahwa total penerimaan petani responden pada satu kali musim tanam adalah sebesar Rp 800.250.000,- dengan rata-rata penerimaan sebesar $\mathrm{Rp}$ 76.214.286,-.

Pendapatan digunakan untuk mengetahui besarnya keuntungan yang diperoleh dari usahatani tanaman cabai merah dalam satu musim tanam. 
Pendapatan adalah hasil pengurangan antara penerimaan total dengan seluruh biaya yang dikeluarkan dalam proses usahatani cabai merah. Pendapatan yang diperoleh akan memberikan gambaran tentang keadaan usahatani cabai merah di Desa Duriasi, maka pendapatan petani responden cabai merah dapat dihitung dengan menggunakan rumus :

$\mathrm{NR} \quad=\mathrm{TR}-\mathrm{TC}$

$N R=$ Rp 76.214.286, $-\operatorname{Rp} 24.918 .512,-$ $\mathrm{NR}=\mathrm{Rp} 51.295 .774,-$

Dari hasil analisis pendapatan petani responden cabai merah adalah rata-rata sebesar Rp 51.295.774,- dalam satu kali tanam.

Tabel 7.Total Biaya, Penerimaan, dan

Pendapatan Usaha Tanaman Cabai

Merah di Desa Duriasi Kecamatan

Wonggeduku Kabupaten Konawe, Tahun 2017.

\begin{tabular}{|l|l|l|}
\hline No. & \multicolumn{1}{|c|}{ Uraian } & \multicolumn{1}{c|}{ Nilai } \\
\hline 1. & Penerimaan & 76.214 .286 \\
\hline \multirow{2}{*}{2.} & Biaya Tetap & 3.549 .179 \\
\cline { 2 - 3 } & Biaya Variabel & 21.369 .333 \\
\hline 3. & Biaya Total & 24.918 .512 \\
\hline 4 & Pendapatan & 51.295 .774 \\
\hline
\end{tabular}

Analisis R/C Ratio merupakan salah satu analisis yang digunakan untuk mengetahui apakah suatu unit usaha dalam melakukan proses produksi mengalami kerugian, impas, atau untung. Analisis R/C Ratio merupakan analisis yang membagi antara penerimaan dengan total biaya yang dikeluarkan. Adapun kelayakan usaha komoditas tanaman cabai merah digunakan persamaan :

$\mathrm{R} / \mathrm{C}=\frac{\text { Total Penerimaan }}{\text { Total Biaya }}$

$\mathrm{R} / \mathrm{C} \quad \frac{76.214 .286}{24.918 .512}$

$\mathrm{R} / \mathrm{C}=3,06$

Dengan kriteria hasil :

- Jika R/C > l usaha komoditas tanaman cabai layak untuk diusahakan.

- Jika R/C < l usaha komoditas tanaman cabai tidak layak untuk diusahakan.
- Jika $\mathrm{R} / \mathrm{C}=1$ usaha komoditas tanaman cabai impas (tidak untung maupun merugi).

$\mathrm{R} / \mathrm{C}$ ratio berdasarkan hasil analisis diatas diperoleh $\mathrm{R} / \mathrm{C}$ sebesar 3,06. Nilai $\mathrm{R} / \mathrm{C}$ ratio lebih besar dari satu $(\mathrm{R} / \mathrm{C}>1)$, hal ini berarti bahwa dalam usaha komoditas tanaman cabai merah yang dilakukan oleh petani responden di Desa Duriasi Kecamatan Wonggeduku Kabupaten Konaew adalah efisien atau layak untuk diusahakan dan setiap satu rupiah yang dikeluarkan akan menghasilkan penerimaan sebesar 3, 06 rupiah.

\section{Tinjauan Ekonomi Islam Terhadap Kelayakan Usaha Komoditas Cabai Merah}

Dalam rangka memenuhi kebutuhan hidup ini, manusia dalam ajaran Islam diperintahkan pula untuk selalu bekerja dan berusaha. Walaupun berbagai aktifitas yang dilakukan oleh manusia untuk memenuhi kebutuhan hidupnya sudah dilaksanakan semaksimal mungkin, namun hasilnya tetap ditentukan oleh Allah, al-Qur'an menerangkan bahwa ketidak merataan karunia dan kesempatan yang dilimpahkan pada masing-masing individu dan bangsa adalah disengaja oleh Allah (Husaini dalam Hasibuan, 2013).

Ekonomi merupakan bagian integral dari ajaran Islam, dan karenanya Ekonomi Islam akan terwujud hanya jika ajaran Islam diyakini dan dilaksanakan secara menyeluruh. Ekonomi Islam mempelajari perilaku ekonomi individu-individu yang secara sadar dituntun oleh Al-Qur'an dan Sunnah dalam memecahkan masalah yang dihadapinya (Barokah, 2011).

Menurut ekonomi Islam usaha atau berusaha merupakan kewajiban tiap individu untuk memenuhi kebutuhan baik berupa sandang dan pangan, karena berusaha itu merupakan identitas Islam. Islam memandang waktu harus dimanfaatkan dengan sebaik mungkin 
untuk berusaha. Dengan ekonomi Islam tidak ada masalah dengan usaha tanaman pangan dan holtikultura khususnya tanaman komoditas cabai merah asal tidak merugikan orang lain dan lingkungan.

Pada dasarnya manusia dalam kehidupan melakukan sesuatu untuk mendatangkan hasil dalam pemenuhan kebutuhan hidupnya. Di dalam Islam, Muhammad Bin Hasan al-Syaibani dalam kitabnya al-Iktibab fi al-Rizq al- Mustathab seperti yang dikutip oleh Adiwarman Azwar Karim, bahwa bekerja dan berusaha merupakan unsur utama produksi mempunyai kedudukan yang sangat penting dalam kehidupan, karena menunjang pelaksanaan ibadah kepada Allah Swt, dan karenanya hukum bekerja adalah wajib (Adiwarman, 2004).

Dalam Islam memposisikan bekerja atau berusaha sebagai kewajiban setelah sholat. Oleh karena itu apabila dilakukan dengan ikhlas maka bekerja atau berusaha itu nilainya ibadah dan mendapat pahala. Pada dasarnya Allah telah menjanjikan rizki untuk makhluknya yang ada di permukaan bumi ini, namun untuk mendapatkannya kita dituntut untuk bekerja dan berusaha. Manusia dan kehidupannya dituntut untuk melakukan sesuatu usaha untuk mendatangkan hasil dalam pemenuhan kebutuhan hidupnya. Dengan berusaha kita tidak saja menghidupi diri kita sendiri, tetapi juga menghadapi orang-orang yang ada dalam tanggung jawab kita dan bahkan bila kita sudah berkecukupan dapat memberikan sebagian dari hasil usaha kita untuk menolong orang lain yang memerlukan. $\mathrm{Hal}$ ini berarti bahwa usahatani komoditas cabai merah merupakan kegiatan yang dilakukan oleh masyarakat di Desa Duriasi Kecamatan Wonggeduku yang usahakan oleh petani responden untuk menghasilkan cabai merah sangat baik untuk dikembangkan karena dapat meningkatkan pendapatan untuk memenuhi kebutuhan sehari-hari. Bukan saja dapat meningkatkan tingkat pendapatan untuk petani tetapi juga dapat meningkatkan tingkatkan kesejahteraan masyarakat khususnya petani cabai merah sehingga dapat terhindarkan dari kemiskinan. bukankah memenuhi kebutuhan keluarga dari hasil keringat usaha mandiri itu sangat mulia disisi Islam, apalagi untuk bisa menafkahi semua anggota keluarga.

Firman Allah dalam al-Qur'an surat al-Ankabuut ayat 69 yang artinya sebagai berikut.

Artinya: "Dan orang-orang yang beriihad untuk (mencari keridhaan) kami, benarbenar akan kami tunjukkan kepada mereka jalan-jalan kami. Dan Sesungguhnya Allah benar-benar beserta orang-orang yang berbuat baik". (Depag RI; Al-Qur'an dan Terjemahnya, 2002).

Berbagai jenis usaha yang dilakukan orang-orang sesuai dengan bidangnya masing-masing tujuannya adalah untuk meningkatkan tingkat pendapatan dan tingkat kesejahteraan.

Pendapatan yang diperoleh responden dalam penelitian ini adalah untuk memenuhi kebutuhan dan mempertahankan kehidupan yang layak agar jauh dari lingkaran kemiskinan.

Dalam Islam, bekerja di nilai sebagai suatu kebaikan, dan kemalasan di nilai sebagai suatu kejahatan. Kemalasan mendekatkan kita ke kemiskinan, dimana kemiskinan dapat mendatangkan kekhufuran nikmat dari Allah SWT. Bukankah Allah dan Rasul-Nya mengajarkan kita untuk giat bekerja dan berusaha? karena ibadah yang paling baik adalah bekerja, dan pada saat yang sama bekerja merupakan hak sekaligus kewajiban diajarkan dalam Islam. Oleh karena itu Islam menetapkan manusia bekerja pada kedudukan yang sangat tinggi, Allah cinta kepada hamba yang mempunyai kerja baik itu dibidang pertanian maupun non pertanian. Dan barang siapa berusaha bekerja dengan 
keras untuk mencari rezeki maka dia akan mendapatkan pahala dari Allah SWT.

Islam mendorong umatnya untuk mencari rezki yang berkah dan halal, mendorong untuk berproduksi, dan menekuni aktivitas ekonomi diberbagai bidang usaha seperti pertanian, perkebunan, perikanan dan kelautan, perdagangan dan perindustrian,, dan bidang sektor lainnya sesuai dengan keinginan dan keterampilan yang dimiliki untuk meningkatkan tingkat kesejahteraan dan kemakmuran keluarganya dan umat secara umum.

Dalam Islam melarang menyianyiakan potensi material, sumber daya manusia maupun potensi sumber daya alam. Bahkan Islam mendorong umatnya untuk memanfaatkan potensi-potensi tersebut untuk kepentingan produksi menjadi sesuatu yang mempunyai nilai tambah dan nilai guna bagi manusia dalam menjalankan kehidupannya dimuka bumi ini sebagai khalifah yang di dalamnya terdapat faktor itqan (profesionalitas) yang dicintai Allah dan insani yang diwajibkan Allah. Sebagaimana Allah berfirman dalam Q.S. at-Taubah: 105 berikut.

Artinya: "Dan Katakanlah: "Bekerjalah kamu, Maka Allah dan rasul-Nya serta orangorang mukmin akan melihat pekerjaanmu itu, dan kamu akan dikembalikan kepada (Allah) yang mengetahui akan yang ghaib dan yang nyata, lalu diberitakan-Nya kepada kamu apa yang Telah kamu kerjakan". (Depag RI; Al-Qur'an dan Terjemahnya, 2002).

Dari ayat diatas dapat di ketahui bahwa Islam sangat menganjurkan kepada setiap pemeluknya untuk bekerja dan dengan niat yang ihklas untuk menjaga amanat dari Allah Swt dan melaksanakan tugas sebagai khalifah, baik khalifah bagi diri sendiri maupun keluarga Hal ini sesuai dengan adanya gagasan untuk berusaha menanam komoditas cabai merah yang agar para petani dapat memanfaatkan dan mengembangkan sumber daya alam yang berupa tanah yang sangat luas untuk diolah dan menghasilkan produksi sehingga dapat bernilai tambah bagi penghasilan. Hasil usaha dari tanaman cabai merah ini dapat mewujudkan kesejahteraan dan meningkatkan taraf kehidupan yang layak bagi petani yang mana sebagian besar adalah muslim dan dapat bernilai ibadah dan pahala jika di sertai ketulusan niat yang baik dan ikhlas.

\section{KESIMPULAN}

1. Berdasarkan hasil analisis diperoleh $\mathrm{R} / \mathrm{C}$ sebesar 3,06. Nilai R/C > 1, hal ini berarti bahwa dalam usaha komoditas tanaman cabai merah yang dilakukan oleh petani responden di Desa Duriasi Kecamatan Wonggeduku adalah efisien atau layak untuk diusahakan dan setiap satu rupiah yang dikeluarkan akan menghasilkan penerimaan sebesar 3, 06 rupiah.

2. Menurut tinjauan ekonomi Islam terhadap kelayakan usaha tanaman komoditas cabai merah telah sesuai dengan prinsip Ekonomi Islam karena dapat mewujudkan tingkat kesejahteraan dan meningkatkan tingkat pendapatan ekonomi keluarga masyarakat, khususnya petani.

\section{DAFTAR PUSTAKA}

[PPHP] Direktorat Jenderal Pengolahandan Pemasaran Hasil Pertanian Kementerian Pertanian. 2014. Statistik Ekspor Impor Komoditas Pertanian 2001-2013. Jakarta:Direktorat Jenderal Pengolahan dan Pemasaran Hasil Pertanian Kementerian Pertanian.

Adiwarman Azwar Karim. 2004. Sejarah Pemikiran Ekonomi Islam. Jakarta: Raja Grafindo. 
Aisyah, Ly Fairuzah. 2011. Tinjauan Ekonomi Islam terhadap Usaha Bisnis Busana Muslim (Studi pada CV. Azka Syahrani Collection). Skripsi Konsentrasi Perbankan Syari'ah Program Studi Muamalat (Ekonomi Islam) Fakultas Syariah dan Hukum UIN Syarif Hidayatullah Jakarta.

Arikunto, Suharsimi. 2010. Prosedur Penelitian : Suatu Pendekatan Praktik. Revisi 14. Jakarta : Rineka Cipta.

Asriya. 2012. Analisis Sistem Agribisnis Lobter Laut Budidaya di Kecamatan Soropia Kabupaten Konawe. Tesis Universitas Haluoleo Pasca Sarjana Program Studi Agribisnis.

Available online with update at:http://Analisis

Finansial.com/(Verified 5th February 2017).

Barokah, Ika. 2011 Prospek Bisnis Kelapa Sawit Pada PT. Perkebunan Nusantara V Pekanbaru Terhadap Perkembangan Ekonomi Daerah Ditinjau Menurut Ekonomi Islam (studi kasus di Sungai Galuh Kecamatan Tapung). Skripsi Jurusan Ekonomi Islam Fakultas Syariah dan Ilmu Hukum UIN Sultan Syarif Kasim Riau.

Budiono. 2004. Buletin Teknik Pertanian. Yogyakarta . Vol. 9 No. 2. [08 Januari 2014].

Dahlan, Ahmad. 2009. Pengantar Ekonomi Islam. Purwokerto: STAIN Press.

Darsono. 2008. Metodologi Riset Agribisnis Buku II Metode Analisis Data. Program Studi Magister Manajemen Agribisnis Program Pascasarjana UPN Veteran. Surabaya. Available online with update at:
Depag RI, Al-Qur'an dan Terjemahan (Semarang:PT Karya Toha Putra, 2002)

Departemen Pertanian R.I. 2015. Program dan Kegiatan Departemen Pertanian. Departemen Pertanian R.I.

Dinas Pertanian Kabupaten Konawe. 2015.

Dinas Pertanian Kabupaten Konawe. 2016.

Elisabeth, Dian Adi A et al. 2006. Analisis Finansial Usaha Pembuatan Virgin Coconut Oil (Vco) Cara Fermentasi. Balai Pengkajian Teknologi Pertanian Bali.

Hartono, Rudi. 2015. Analisis Ekonomi Usahatani Cabai Di Propinsi Bengkulu. Balai Pengkajian Teknologi Pertanian Bengkulu.

Hasibuan, Juliati. 2013. Kontribusi Perkebunan Coklat Dalam Meningkatkan Pendapatan Rumah tangga Ditinjau dari Ekonomi Islam (Studi Kasus Pada Kecamatan Kabupaten Indragiri Hulu). Skripsi Fakultas Syari'ah dan Ilmu Hukum UIN Sultan Syarif Kasim Pekanbaru Riau.

http://Riset Agribisnis.com/(Verified 20th February 2010).

http://.pskomnas.com/id/berita/

Kahana, Budi Pamilih. 2008. Strategi Pengembangan Agribisnis Cabai Merah di Kawasan Agropolitan Kabupaten Magelang. Tesis Universitas Diponegoro Pascasarjana Program Studi Agribisnis. Semarang. 
Kasmir dan Jaktar. 2009. Studi Kelayakan Bisnis. Edisi Revisi. Jakarta : Kencana Prenada Media Grup.

Khazanani, Annora. 2011. Analisis Efisiensi Penggunaan Faktor-FaktorProduksi Usahatani Cabai Kabupaten Temanggung (Studi Kasus di Desa Gondosuli Kecamatan Bulu Kabupaten Temanggung). Skripsi Fakultas Ekonomi Universitas Diponegoro Semarang.

Nasution, Mustafa Edwin. 2007. Pengenalan Eksklusif Ekonomi Islam.Jakarta : Kencana.

Parwadi S. 2014. Stabilisasi harga cabe merah o bawang merah, pasar komoditi nasional. [23 Januari 2015].

Prajnanta, F. 1999. MengatasiPermasalahan Bertanam Cabai. Penebar Swadaya. Jakarta.

Qardhawi, Yusuf. 1997. Norma dan Etika Ekonomi Islam. Jakarta: Gema Insani Press Cetakan ke-l.

Rukmana, R. 2001. Cabai Hibrida Sistem Mulsa Plastik. Kanisius. Yogyakarta.

Sahatan, Husein. 1998. Ekonomi RumahTangga Muslim. Jakarta: Gema Insani Press.

Saleh, Leni. 2010. Produktivitas dan Efisiensi Usaha Tani Tanaman PadiSawah di Kabupaten Konawe. Tesis

Samadi, B. 2007. Budidaya Cabai Merah Secara Komersial. Yayasan Jurnal Manajemen Pustaka Nusatama. Yogyakarta.
Santika, A. 1999. Agribisnis Cabai. Penebar Swadaya. Jakarta.

stabilitasiharga-cabe-bawang merah.php. Sugiyono. 201l. Metode Penelitian Kuanitatif, Kualitatif dan Riset Development. Bandung : Alfabeta.

Sumarni, N., dan A. Hidayat. 2005. Juknis Budidaya Bawang Merah. Balai Penelitian Tanaman Sayuran. Pusat Penelitian dan Pengembangan Hortikultura Badan Penelitian dan Pengembangan Pertanian.

Suratiyah, K. 2008. Ilmu Usahatani. Penebar Swadaya, Jakarta.

Susanto AN, Sirappa MA. 2007. Karakteristik dan ketersediaan data sumber daya lahan pulau-pulau kecil untuk perencanaan pembangunan pertanian. Jurnal Penelitian dan Pengembangan Pertanian 26(2) : 41-53.

Syafrisal. 1997. Pertumbuhan Ekonomi dan Ketimpangan Regional WilayahIndonesia Bagian Barat. Prisma : 27-38.

Unpublished Universitas Gadjah Mada Pascasarjana Program Studi Ekonomi Pertanian Fakultas Pertanian. Yogyakarta. 